\author{
Ainis Razma* \\ Vilniaus universiteto Ekonomikos fakultetas
}

\title{
Centrinès Azijos geopolitika po 2014 m. Krymo aneksijos
}

2014 metų kovo viduryje Rusijos ịvykdyta Krymo aneksija - tai ịvykis ryškiai išsiskiriantis iš bendro po Šaltojo karo pabaigos besiklostančio tarptautinių santykių konteksto. Pirmą kartą po Antrojo pasaulinio karo pabaigos Europoje jèga aneksuota suverenios valstybès teritorijos dalis, o tai reiškia, kad sienų perbraižymas ir revizionizmas platesne prasme jau tapo tarptautinių santykių realybe, vienu iš veiklos principų ir būdų. Tikètina, jog tokio masto įvykio pasekmès turètų būti jaučiamos ne tik tame pačiame regione, bet ir tolimesniuose, geopolitiškai jautriuose pasaulio regionuose. Straipsnyje nagrinejjama, kaip Rusijos veiksmai Ukrainoje paveikè Centrinès Azijos geopolitiką ir kokios jų pasekmès tikètinos ateityje. Daroma prielaida, kad dèl Krymo aneksijos Centrinès Azijos šalys ėmè gręžtis ị vieną iš dviejų konfrontuojančiu galios centrų - ị Vakarų arba ị Rusijos. Dèl šios besiformuojančios tendencijos ị tarptautinius santykius grị̌ža strateginès konfrontacijos mentalitetas. Poliarizacijos tendencija, atrodo, tampa geopolitiniu veiksniu, darančiu įtaką Centrinès Azijos galios dinamikai, jos kultūrai, ekonomikai, karinei struktūrai. Kultūriškai poliarizacija yra nesuderinama su Centrinès Azijos valstybių užsienio politikos daugiavektoriškumo nuostatomis, todèl jos poveiki bandoma neutralizuoti susilaikant nuo vienareikšmių Ukrainos situacijos vertinimų. Tačiau, toks santūrumas niekaip nesumažina karinių grèsmių, kurios Centrinès Azijos valstybèms tapo aktualios tiek dèl Rusijos politikos Ukrainoje iggvendinimo būdų, tiek ir dèl galimai inspiruojančio tokios politikos poveikio vietinėms separatistinėms jègoms ir radikalioms islamistų grupuotėms. Nuogąstavimai dèl galimo Krymo scenarijaus pasikartojimo ir karinès grèsmès asimetriškumas gali pastūmèti Centrinès Azijos valstybes ieškoti saugumo garantijų už regiono ribų. Tokio vyksmo poveikis regiono stabilumui iš esmès priklausytu jau ne nuo pačių Centrinès Azijos valstybių, o nuo didžiųjų galybių požiūrio ị stabilumo jame užtikrinimą. Jei dominuotų kooperacinis požiūris, Centrinėje Azijoje galètų susiformuoti regioninio balanso sistema, kuri užtikrintų santykinị stabilumą. Didžiųjų galybių siekis užtikrinti stabilumą savo sąlygomis vestų prie regiono destabilizacijos. Alternatyvą šiems ateities scenarijams, regis, gali pasiūlyti Kinija, kurios politika Centrineje Azijoje darosi vis ryžtingesnè ir susilaukia regiono valstybių pritarimo. Rezultatinei regiono galios tendencijai įtakos turés ekonominių santykių dinamika regione, Vakarų sąjunginių karinių pajẻgų išvedimas iš Afganistano, Irano ir Turkijos politika regione ir kiti kontekstą formuojantys veiksniai.

\footnotetext{
*Ainis Razma - Vilniaus universiteto Ekonomikos fakulteto lektorius. Adresas korespondencijai: Saulètekio al. 9, II rūmai, 10222 Vilnius, tel. (8 5) 236 6146, el. paštas: ainis.razma@ef.vu.lt.
} 


\section{Ivadas}

$2014 \mathrm{~m}$. kovo ménesị Rusijos ịvykdyta dalies Ukrainos teritorijos aneksija labai paveikè tarptautinių santykių sistemą, susiformavusią po Antrojo pasaulinio karo, sužadindama poliarizacijos tendenciją. Pradejjusi reikštis, ši tendencija tampa geopolitiniu veiksniu, kurio poveikis dabarties kontekstams kol kas mažai tyrinètas. Tiesa, įvykiai Ukrainoje ir jų pasekmès susilaukẻ nemažo tyrëjų dèmesio ${ }^{1}$, tačiau dauguma studijų šiuo klausimu kol kas apsiribojo krizès regiono situacijos analize. O bandymų apmąstyti, kaip Ukrainos ịvykiai veikia platesnị tarptautinių santykių kontekstą aptinkama nedaug². Tokiose studijose pirmiausia bandoma išgryninti sèkmingos Rusijos agresijos Ukrainoje prielaidas ir domimasi, ar tokios prielaidos egzistuoja kitur, ypač posovietinèje erdveje $e^{3}$. Tai skatina geriau panagrinèti kaip, Ukrainos ịvykiai paveike atskirus regionus. Vienas iš regionų, kuriame gana intensyviai sąveikauja Vakarai, Rusija, o taip pat ir Kinija, yra Centrinè Azija. Regionas yra svarbus ekonomikai ir turi geostrateginę vertę, todèl tikètina, jog už regiono ribų vykstanti poliarizacija veiks nemažai Centrinès Azijos politikos aspektų, galimai sužadins jau esamus nestabilumo veiksnius ar kels naują itampą. Jau pasirode keli straipsniai, nagrinėjantys konkrečius Centrinès Azijos valstybių reakcijos ị Ukrainos ịvykius aspektus, tarp jų Vakarų ekonominių sankcijų Rusijai poveikị Kazachstano finansų sistemai ${ }^{4}$, oficialų Kirgizstano pareiškimą apie Krymą, ${ }^{5}$ ir svarstantys, kaip Ukrainos įvykiai gali paveikti Centrinès Azijos valstybiu politiką Rusijos atžvilgiu trumpalaikeje ir ilgalaikeje perspektyvoje. ${ }^{6}$

Šio straipsnio tikslas yra išnagrinèti kokią itaką Centrinès Azijos geopolitikai gali turèti poliarizacija. Remiantis ligšioliniais Centrinès Azijos politikos tyrinèjimais ir žiniasklaidos pranešimais apie pastarųjų mėnesių ịvykius, siejančius Ukrainos ir Centrinès Azijos politinị vyksmą, bus siekiama numatyti,

\footnotetext{
${ }^{1}$ Mankoff J., "Russia’s Latest Land Grab: How Putin Won Crimea and Lost Ukraine", Foreign Affairs 93.3 (2014): 60-68; Chesterman G., G., "The Russian annexation of Crimea in March 2014", United Service, vol.65 (2), Winter 2014; M., R. W. "Should Crimea Secede from Ukraine and Become Part of Russia (Again)?" Available at SSRN 2403479 (2014).

${ }^{2}$ Ding Sh., "China’s dilemma in the Ukraine crisis" (2014), Asia Pacific Bulletin, No.255, 201403 27, Granholm N., Malminen J., Persson G., eds, A Rude Awakening. Ramications of Russian Aggression Towards Ukraine, FOI, June 2014.

${ }^{3}$ Norberg J., ed., Franke U., Westerlund F., “The Crimea Operation: Implications for Future Russian Military Interventions", in Granholm N., Malminen J., Persson G., eds, A Rude Awakening. Ramications of Russian Aggression Towards Ukraine, FOI, June 2014.

${ }^{4}$ Brauer B., "Cost of Black Tuesday for Kaazkhstan", Central Asia-Caucasus Analyst, 201403 19, p.13-15.

${ }^{5}$ Sabyrbekov A., "Bishkek's First Official Statement on Ukraine", Central Asia-Caucasus Analyst, 201403 19 , p. 16-17.

${ }^{6}$ Hórak S., "Russia’s Intervention in Ukraine Reverberates in Central Asia", Central Asia-Caucasus Analyst, 201403 19, p. 9-12.
} 
kaip poliarizacija galètų veikti karinio, ekonominio ir kultūrinio-informacinio galios elementų dinamiką Centrinejje Azijoje. Šias užduotis numatoma atlikti pasitelkus geopolitinès analizès metodologiją. Analizė bus atliekama subsisteminiu ir sisteminiu lygmenimis. Sistema šiame straipsnyje bus laikomas Centrinès Azijos regionas, geografiškai apibrèžtas Kazachstano, Kirgizstano, Tadžikistano, Turkmėnistano ir Uzbekistano išorinių sienų perimetru. Sistemos dinamika čia suvokiama kaip regiono valstybių politikos pokyčiai dèl tikètino nagrinëjamo geopolitinio veiksnio poveikio. Tad pagrindinis analizès klausimas sisteminiu lygmeniu - kokią ịtaką šalių, esančių už regiono ribų, poliarizacija (t. y. didžiụjų pasaulio politikos veikèjų tarpusavio santykių pobūdžio kaita) turès galios dinamikai Centrinès Azijos regione? Subsisteminiu straipsnyje bus laikomas atskiros Centrinès Azijos valstybès lygmuo. Čia bus nagrinejjama, kaip kiekviena iš šių valstybių reagavo ị ịvykius Ukrainoje ir bandoma paaiškinti tokios reakcijos priežastis. Analizè pradedama subsisteminiu lygmeniu, vèliau pereinama prie sisteminio lygmens. Rezultatinè galios regione tendencija pateikiama išvadų dalyje.

Pagrindinio analizès klausimo formuluotė atspindi siekị straipsnyje aptarti galimas ateities perspektyvas. Prognozavimo metodikos požiūriu straipsnis laikytinas individualiu ekspertiniu vertinimu ir priskirtinas deskriptyvinès prognozės sričiai ${ }^{7}$. Straipsnio išvadų dalyje pateikiamos kelios galimos ateities alternatyvos, tad iš dalies čia bandoma konstruoti scenarijus.

Tiriant bus laikomasi neoklasikinio realizmo paradigmos, pagrindiniu analizès vienetu laikant valstybę arba politinę sistemą (ES). Straipsnyje analizės vienetu laikoma taip pat ir reifikacija „Vakarai“, reiškianti valstybes, ̨̣einančias ị liberalios demokratijos erdvę. Toks reifikavimas argumentuojamas ir vartojamas tik tuo atveju, kai turimos galvoje bendros šias valstybes vienijančios užsienio politikos nuostatos dèl sienų Europoje neliečiamumo, tarptautinès teisès principų laikymosi ir kitų.

\section{Poliarizacija kaip geopolitinis veiksnys}

Po Krymo aneksijos tarptautiniuose santykiuose besireiškiančiai poliarizacijos tendencijai, regis, būdinga VakarųRytų orientacija, tad galima įžvelgti tam tikrų šiandieninès situacijos Europoje panašumų su Šaltojo karo epocha. Tačiau skirtumai tarp jų yra esminiai. Kaip ir Šaltojo karo metu, Vakarai vèl

\footnotetext{
${ }^{7}$ Janeliūnas T., Kasčiūnas L., „Prognozavimo metodų taikymas politikos moksluose“, Politologija, 2007, Nr. 3, p. 20.
} 
tampa geopolitine sąvoka, konkrečiai reiškiančia valstybes, įeinančias ị liberalios demokratijos erdvę. Tačiau, dabartineje poliarizacijoje sąvoka „Vakarai“ apima ir dalį Šaltojo karo metu Rytams priskirtų šalių. O sąvokai „Rytai“ šiandien vargu, ar tikslinga suteikti geopolitinę prasmę, nes Krymo aneksijos kontekste ji apima išskirtinai tik Rusiją, o ne kokị nors platesnị, ideologiniais ar geopolitiniais motyvais grindžiamą, valstybių darinị. Tad dabartinè pasaulio politinès sistemos poliarizacija pasižymi tuo, jog Rusija pereina ị atvirą oponavimą Vakarams. Regis, jog ji vadovaujasi ne tiek ideologiniais, kiek geopolitiniais sumetimais, tad situacija veikiau primena XIX-XX a. pradžios Europą, negu Šaltajji karą.

Pirmiausia pastebimas poliarizacijos proceso kultūrinis-informacinis matmuo. Iš pradžių jis reiškiasi vis griežtejjančia politine retorika tarp sistemos polių. Vèliau daugiausia per žiniasklaidą, imami formuoti tam tikri savo ir priešingo poliaus ịvaizdžiai, dažnai paremiami archetipiniais vaizdiniais ir politiniais mitais. Galiausiai poliarizacija tampa vienu iš pagrindinių tapatybès šaltinių, esmine „mes“ ir „kiti“ skirties sąlyga. Tokiu būdu poliarizacijos kultūrinis-informacinis dèmuo daro įtaką strateginès priešpriešos mentaliteto formavimui ar atgaivinimui, o pastarojo vystymosi vektorius veda nulinės sumos žaidimo logikos ịsitvirtinimo link daugumoje oponuojančių polių plotmių santykių. Strategineje priešpriešoje tarp Vakarų ir Rusijos taip pat reiškiasi poliarizacijos kariniai ir ekonominiai dėmenys. Rusijos strateginių bombonešių skrydžiai arti JAV objektų, puolimo prieš Vakarų valstybių objektus imitavimas karinių mokymų metu rodo, jog Rusija neatmeta karinès kolizijos su Vakarais galimybės. Savo ruožtu NATO atvirai ịvardijo Rusiją kaip grèsmę Europai. ${ }^{8}$ Abiems poliams demonstruojant karines galimybes, kol kas veikiama ekonomikos plotmèje, taikant tiesiogines ir skelbiant atsakomąsias sankcijas. Ekonominiame kontekste Vakarams tapo itin aktualus ES priklausomybės nuo Rusijos energetinių resursų klausimas. Siekiant ją sumažinti, JAV iš principo sutinka liberalizuoti savo gamtinių dujų eksportą ir pradëjo su ES derybas šiais klausimais. Tuo pačiu metu prezidentas Barackas Obama ne kartą užsiminè, jog ES „,negali remtis vien tik kitų šalių energija, net jei tai ir susiję su didesnèmis išlaidomis ar kokiais nors kitais trūkumais" ${ }^{\text {"9 }}$, akivaizdžiai ragindamas persvarstyti pastaruosius dešimtmečius Europoje įsivyravusias skalūnų bei pakrantės šelfo dujų gavybos, o taip pat branduolinès energetikos nuostatas. Kitaip tariant, judama Vakarų energetinio atsiribojimo nuo Rusijos link. Vakarams atsiribojus nuo Rusijos, ES visiškai at-

\footnotetext{
${ }^{8}$ Rettman A., "NATO Chief Describes “Outrageous" Russia as Threat to Europe", Eurobserver, 201405 14, http://euobserver.com/defence/124184, 20140612.

${ }^{9}$ Emmot R., Strupczewski J., "Obama Tells EU To Do More To Cut Reliance on Russian Gas", Reuters, 201403 26, http://www.reuters.com/article/2014/03/26/us-usa-eu-summit-idUSBREA2P0W220140326, 20140601.
} 
siskirs nuo Rusijos dujų tiekimo arba bent jau sukurs sistemą, užtikrinančią ES energetinių poreikių patenkinimą ir be Rusijos dalyvavimo.

Būtina pabrèžti, jog čia kalbama apie ižželgiamas tendencijas, tarptautinių santykių vystymosi kryptį, o ne konstatuojamas įvykęs poliarizacijos faktas, visiškas perëjimas prie nulinès sumos žaidimo logikos Vakarų santykiuose su Rusija. To daryti neleistų, pavyzdžiui, Prancūzijos ketinimas tęsti „Mistral“ laivų pardavimo Rusijai sutarties vykdymą, palaikomi kai kurių Vokietijos pramonès įmonių ryšiai su Rusija, ar NATO viduje vykstanti diskusija tarp reikalaujančių reaguoti ị Rusiją kaip ị grèsmę ir kviečiančių palaukti su išvadomis, stebėti tolesni situacijos Rytų Ukrainoje vystymąsi. Tai gali reikšti keletą dalykų. Viena vertus, galima būtų teigti, jog nepaisant Krymo aneksijos akivaizdumo, ịtvirtinti Rusijos grèsmès suvokimą Vakarų politinèje sąmonèje reikalingas laikas. Tokio pobūdžio diskusijose dažnai prisimenama akivaizdžiai agresyvi Adolfo Hitlerio politika nuo Rūro srities militarizavimo iki kitų valstybių dalies teritorijų aneksijos ir Antrojo pasaulinio karo pradžios. ${ }^{10} \mathrm{Kita}$ vertus, nevertètų atmesti prielaidos, kad geopolitinis primityvumas nèra vien Rusijos užsienio politikos bruožas, bet taip pat tam tikru lygiu pasireiškia ir Vakarų Europos valstybių, pavyzdžiui, jau minètų Vokietijos ir Prancūzijos, veiksmuose. Vien geopolitiniais argumentais pagrịsti Krymo aneksijos ịtaką Vakarų Europos saugumui būtų gana sunku. Čia reikètų kalbèti ne tik apie geopolitiką, bet ir apie teisę, tiksliau, grèsmę keliančius susiklosčiusio teisinio režimo pažeidimus. Galima manyti, kad principo taikymas bus ribotas, sustos ties tam tikra riba. Kitaip tariant, bus pripažintos įtakos zonos ir tokio pripažinimo pagrindu galima būtų toliau palaikyti konstruktyvius ir abiem pusèms naudingus santykius. Skirtinga geopolitinio dèmens svarba politikoje galbūt sąlygojo ir tebesąlygoja gana ryškius JAV ir ES retorikos apie Rusiją skirtumus.

\section{Centrinès Azijos valstybès Ukrainos įvykiu akivaizdoje}

Visų Centrinès Azijos valstybių užsienio politikai, ịskaitant ir neutraliteto besilaikantị Turkmènistaną, būdingas skirtingu lygiu besireiškiantis daugiavektoriškumas. Poliarizacijos veiksnio kultūrinis-informacinis aspektas iš esmès yra ideologiškai nesuderinamas su šių valstybių deklaruojamomis politi-

\footnotetext{
${ }^{10}$ Keneally M., "Hillary Clinton Compares Russia's Invasion toUkraine to 'What Hitler Did Back in 30s' Ahead to WWII', Mail Online, 201403 15, http://www.dailymail.co.uk/news/article-2573810/HillaryClinton-compares-Russias-invasion-Ukraine-Hitler-did-30s-ahead-WWII.html, 20140316.
} 
kos nuostatomis, todèl Ukrainos ịvykiai tapo rimtu iššūkiu regiono valstybių diplomatiniams santykiams. Oficialios Centrinès Azijos valstybių reakcijos $\mathfrak{i}$ Krymo aneksijos faktą buvo skirtingos. Uzbekistanas oficialiai išreiškè neigiamą požiūrị, pabrèždamas, jog „santykiuose tarp valstybių turi būti susilaikoma nuo kèsinimosi ị teritorinị vientisumą "11. Uzbekistano Prezidentas I. Karimovas, bendro pobūdžio komentaruose apie šiandieninę tarptautinių santykių būklę, su akivaizdžia aliuzija ł̇ Rusiją, teigè, jog „šiuolaikiniame pasaulyje,

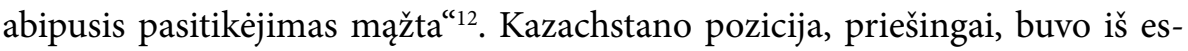
mès palanki Rusijai. Kazachstano Respublikos užsienio reikalų ministerijos pareiškime sakoma, jog Krymo prijungimą prie Rusijos Kazachstanas laiko „autonominès respublikos gyventojų laisvos valios išraiška" ${ }^{13}$. Panašaus turinio, Rusijai palankų pareiškimą išplatino ir Kirgizstanas ${ }^{14}$. Tadžikistanas ir Turkmėnistanas apskritai susilaike nuo oficialių Ukrainos ịvykių komentarų. Visi nagrinètų pareiškimų tekstų raiška gana panaši. Čia dažnai vartojama tariamoji nuosaka, kalbama apie tai, kaip turètų būti, o ne kaip yra; daugiau užsimenama apie veikimo principus, o ne jau atliktus veiksmus. Be to, kai kurie Ukrainos situacijos aspektai interpretuojami taip, kad juos galima būtų vertinti teigiamai (pavyzdžiui, referendumas, kaip visuomenès politinès valios išraiška), o kiti tos pačios situacijos aspektai vertinami kaip tobulintini (sakoma, jog turètų būti gerbiamas teritorinis integralumas). Taip parodant situacijos daugiareikšmiškumą, tarsi sudaroma galimybe išvengti vertinimo pagal priklausymą tam tikram politiniam poliui. Kitaip tariant, bandoma sumažinti kultūrinio-informacinio poliarizacijos aspekto reikšmę, pasitelkiant tiek „už“, tiek ir „pries“" argumentus.

Nors siunte skirtingas oficialias žinutes, tačiau praktiškai Centrinès Azijos valstybès elgèsi panašiai ir tai, regis, rodo, jog Rusija yra suvokiamas kaip grèsmingesnis polius. Po to, kai Rytų Ukrainoje separatistai užèmé keletą televizijos stočių ir pradejo savo transliacijas, $2014 \mathrm{~m}$ balandžio $14 \mathrm{~d}$. Uzbekistano vyriausybė prièmé nutarimą užminuoti visas televizijos ir radijo stotis, kad jas galima būtų tuojau pat susprogdinti, jei tik jomis būtų bandoma pasinaudoti

\footnotetext{
11 "The Position of the republic of Uzbekistan on the Situation in Ukraine and the Crimean Issue", Ministry of Foreign Affairs of the Republic of Uzbekistan, 2014 03 25, http://www.mfa.uz/en/press/ news/2014/03/1529/, 20140325.

${ }^{12}$ Azizov D., "Uzbek President Says Trust is Most Important Element in Strengthening Int'l Cooperation", Trend, 201405 22, http://en.trend.az/regions/casia/uzbekistan/2276997.html, 20140525.

13 "Statement by the Minsitry of Foreign Affairs of Kazakhstan on the Referendum in Crimea", Ministry of Foreign Affairs of Kazakhstan, 201403 18, http://mfa.gov.kz/en/\#!/news/article/13803, 20140318. ${ }_{14}$ "Statement of the Ministry of Foreign Affairs of the Kyrgyz Republic on Situation in Ukraine and Crimea”, Ministry of Foreign Affairs of the Kyrgyz Republic, 2014 03 20, http://www.mfa.kg/vistupleniya/ zayavlenie-ministerstva-inostrannih-del-kirgizskoi-respubliki-ot-20-marta-2014-goda-3_en.html, 20140320 .
} 
priešiškais tikslais. Uzbekistano Respublikos nacionalinio saugumo tarnyba išleido papildomus potvarkius, nurodančius, jog visi ventiliacijos vamzdynai ir šachtos, esantys televizijos ir radijo stotyse turi būti pakeisti ị gerokai mažesnio diametro vamzdžius, kuriais negalima būtų patekti ị vidų. Be to, studijos turi būti įrengtos taip, kad nesusisiektų su jokiomis kitomis patalpomis, ịskaitant tualetus. Uždrausta rengti laidas tiesioginès transliacijos būdu. Šis draudimas galioja taip pat ir žinių laidoms. I̦vesta daug kitų draudimų ir apribojimų. Kazachstane priimtas įstatymas dèl žiniasklaidos veiklos krizès sąlygomis. Dokumentas numato, jog tam tikrais atvejais, naujienų publikavimas gali būti stabdomas 24 valandoms. Dušanbès municipalitetas išleido potvarkị, pagal kurị visos senos ar atsarginès padangos turi būti sandèliuojamos ne arčiau kaip 40 $\mathrm{km}$ nuo miesto ${ }^{15}$. Akivaizdu, jog Centrinès Azijos valstybès akylai stebi, kas vyksta Ukrainoje, kokius taktinius sprendimus priima separatistai ir, vertindamos ten susidarančių situacijų pasikartojimo galimybes Centrinëje Azijoje, siekia užkirsti kelią jų pasikartojimui. Čia galima įžvelgti poliarizacijos poveikị karinio galios elemento dinamikai, kuris, regis, tiesioginis ir sunkiau sumažinamas. Minètasis situacijų vertinimas reiškia, jog Centrinès Azijos valstybės ieško savo viduje prielaidų, panašių ị tas, kuriomis buvo grindžiami Rusijos veiksmai Ukrainoje, ir jos tokių prielaidų randa.

Rusijos veiksmų Ukrainoje kartojimasis gresia ir Kazachstanui. Čia ketvirtadali gyventojų sudaro rusai, o šiauriniuose šalies regionuose ši dalis siekia apie 50 \%. Šiandien, deja, trūksta patikimos informacijos apie Kazachstano rusakalbių nuotaiką ir požiūrị ị Rusiją, bet Kazachstano nepriklausomybès pradžioje vykęs valstybès aparato „valymas“ nuo rusų, kitos segregacijos pagal tautybę apraiškos leidžia daryti prielaidą, jog rusakalbius galètų gana lengvai paveikti Rusijos informacija. Atkreiptinas démesys ir i $2008 \mathrm{~m}$. Aleksandro Solženicyno interviu „Forbes“ žurnalui, kuriame rašytojas teigia manąs, jog „visas Šiaurès ir Šiaurès Rytų Kazachstanas faktiškai yra Pietų Sibiro dalis“, kuriame rusai „patiria priespaudą dèl savo tautybès, tiek kultūriniame gyvenime, tiek verslo reikaluose, tiek ir kasdienybëje “ ${ }^{16}$ Geopolitiškai Šiaurès ir Šiaurès Rytų Kazachstano aneksija Rusijai suteiktų nemažai privalumų, pirmiausia susijusių su galimybe daryti didesnę ịtaką Kinijai. Per šią Kazachstano dalị eina prekybos ir energetikos keliai ị Kiniją, be to, netoliese yra maištinga Kinijos Sindziango provincija, kurioje stipriai ịsišaknijusios uigūrų separatizmo idèjos.

\footnotetext{
${ }^{15}$ Pannier B., „Uzbek Broadcasters Set to Self-Destruct“, Radio Free Europe/Radio Liberty, http://www.rferl. org/content/qishloq-ovozi-uzbekistan-broadcasters-self-destruct/25361053.html, 201404 14, 20140414. 16 "Alexander Solzhenitsyn on the New Russia“, Forbes, 200805 08, http://www.forbes.com/2008/08/05/ solzhenitsyn-forbes-interview-oped-cx_pm_0804russia.html, 20140614.
} 
Lig šiol nebuvo prognozuojama, kad Kazachstano ir Rusijos santykiai galètų prastėti. Kazachstaną ịprasta vertinti kaip patikimiausią ir ịtakingiausią Rusijos sąungininką Centrineje Azijoje. Vis tik, nepaisant 2014 m. gegužès 29 d. pasirašytos Eurazijos Sąjungos sutarties, 2014 metų pabaigoje atsiranda ženklų, jog šalių santykiai blogejja ${ }^{17}$. Be to, atkreiptinas dèmesys ị faktą, ne visiškai derantị prie pasitikejimu grindžiamų Kazachstano ir Rusijos santykių konteksto - $2014 \mathrm{~m}$. kovo 28 d., t. y. praejus dvylikai dienų po Krymo referendumo, Rusija paskelbė planus prie Kazachstano sienų dislokuoti mažo nuotolio balistinių raketų kom-

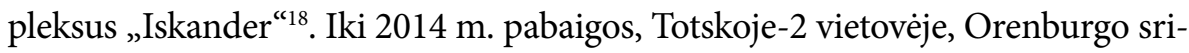
tyje, maždaug $100 \mathrm{~km}$ atstumu nuo Kazachstano sienos, planuojama dislokuoti 12 tokių kompleksų. Rusija ši žingsnị aiškina Kolektyvinio saugumo sutarties organizacijos (KSSO) vykdomomis priemonėmis, kuriomis siekiama palaikyti regiono stabilumą, kai JAV ir sąjungininkai pasitrauks iš Afganistano. Lieka neaišku kodèl šiam tikslui pasirinktas ginklas, kurio veikimo nuotolis nesiekia Afganistano, tačiau siekia beveik visą Kazachstano teritoriją. Čia svarbi aplinkybė, kad Rusija Kazachstane ir taip laiko savo ginkluotąsias pajègas, net neįskaitant specialių, Baikonyro kosmodromą saugančių dalinių.

Uzbekijoje po Krymo aneksijos paaštrèjo situacija Karakalpakijos autonominëje srityje. 2014 kovo 14 d. anksčiau nežinoma grupè „Alga, Karakalpakstan“ opozicinio Uzbekistano politinio judejjimo „Birdamalik“ Facebook paskyroje paskelbè tokio turinio pareiškimą:

Karakalpakijos žmonès nesutinka su [Uzbekistano Respublikos Prezidento Islamo] Karimovo režimo vidaus ir užsienio politika. Karakalpakai nori prisijungti prie Rusijos. Savo kultūra ir kalba, karakalpakai artimesni kazachams, tačiau ar Kazachstano prezidentas paremtų Karakalpakstano Respublikos laisvès ir nepriklausomybès siekį? Jei išgirstumème palankų signalą iš Kremliaus, būtume pasirengę iškelti Rusijos vèliavą. ${ }^{19}$

Krymo aneksija ir ịvykiai Rytų Ukrainoje kelia pagrịstą nerimą Tadžikistano ir Kirgizstano vadovybèms. Šiose Centrinès Azijos valstybėse Rusija laiko didžiausias karines pajègas regione. Tadžikistane yra dislokuota Rusijos Federacijos 201-oji sausumos pajègų divizija, o Kirgizstane yra Kanto aviacijos bazé, kuri neseniai buvo sustiprinta papildomais priešlèktuvinės gynybos pajègumais $^{20}$. Tadžikistane nuogąstaujama, kad Rusija gali bandyti pasinaudoti

\footnotetext{
${ }^{17}$ Casey, Michael, „Russian-Kazakh Relations Took a Dive in 2014“, The Diplomat, 2014 12 20, http:// thediplomat.com/2014/12/russia-kazakhstan-relations-took-a-dive-in-2014/, 20141220.

18 "Russia to Deploy Iskander Missiles at Kazakhstan Border", TengriNews, 201403 28, http:// en.tengrinews.kz/military/Russia-to-deploy-Iskander-missiles-at-Kazakhstan-border-252507/, 20140329. ${ }^{19}$ https://www.facebook.com/birdamlikh, 20140315.

20 "Russia Strengthens Military Bases Abroad - Defense Minister", Ria Novosti, 201405 23, http://en.ria.ru/ military_news/20140523/190068469/Russia-Strengthens-Military-Bases-Abroad--Defense-Minister.html, 20140523.
} 
situacija Pamyre, Kalnų Badachšano regione. Čia jau keletą metų nuolat susiduria neformalios kovotojų grupuotès, kertančios Tadžikistano ir Afganistano sieną, ir šalies kariuomenè. Tadžikų ekspertai mano, jog nemaža dalimi šie susidūrimai gali būti inspiruojami Maskvos, nes padèties destabilizavimas ir šalies vadovybès bauginimas neramumų išplètimu yra palankus plèsti karinị Rusijos kontingentą Tadžikistane ${ }^{21}$. Tokias prielaidas patvirtina faktas, jog 2013 metais Dušanbė sutiko pratęsti Rusijos karinių bazių buvimą Tadžikistane. Tiesa, Tadžikistanas kol kas kategoriškai atsisako leisti Rusijai patruliuoti jo sieną su Afganistanu. Manoma, kad tai yra viena iš priežasčių, kodèl karo veiksmai Kalnų Badachšane pastaruoju metu itin paaštrẻjo. Būtina pabrèžti, kad kol kas šie susiremimai vyksta narkotikų kontrabandos fone ir kad šiame Tadžikistano regione ganètinai lengva įžiebti ir etninius neramumus. Pirmiausia, čia gyvenančios etninès grupès skiriasi nuo tadžikų. Antra, kitaip nei dauguma tadžikų, Kalnų Badachšano musulmonai yra šiitai. Trečia, šio regiono gyventojai turi savitų sentimentų Rusijai. Priešingai nei kitos Tadžikistano teritorijos, Pamyras savanoriškai prisijungè prie Carinės Rusijos. Sovietų Sąjungoje prasidejjus Glasnost reformai, regione atsirado nemažai politikų agitavusių už šio Pamyro regiono atskyrimą nuo Tadžikijos ir prijungimą prie Rusijos. Galbūt jau girdimi ir 2014 metų Ukrainos ịvykių atgarsiai 2014 m. gegužès 22 d. Chorogo mieste vykusių neramumų metu demonstrantai paskelbė rezoliuciją, kurioje teigiama, kad susidūrimai vyksta tarp Kalnų Badachšano (Pamyro) gyventojų ir Tadžikistano centrinès valdžios pajegų ${ }^{22}$. Taigi, situacija, regis, keičiasi ir tokie pasikeitimai greičiausiai skatins tiek Tadžikistaną, tiek ir Kirgizstaną pagal galimybes vengti Rusijos integracinių iniciatyvų.

\section{Centrinè Azija ir didžiosios valstybès: geopolitiné poliarizacija ir jos alternatyva}

Centrinès Azijos valstybių laikymas regionu ar sistema yra sąlyginis, nelygu kaip šios sąvokos bus apibrèžtos. Pačios Centrinès Azijos valstybės turi nemažai tarpusavio skirtumų. Pavyzdžiui, autokratijos lygis jose yra skirtin-

\footnotetext{
${ }^{21}$ Rotar I., “Tajikistan launches Military Operation in Remote Pamirs Region”, Eurasia Daily Monitor, vol. 9, issue 143, 201207 27, http://www.jamestown.org/single/?no_cache=1\&tx_ttnews\%5bswords

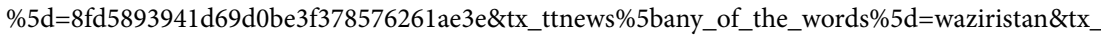
ttnews\%5bpointer\%5d=11\&tx_ttnews\%5btt_news\%5d=39685\&tx_ttnews\%5bbackPid\%5d=7\&cHash=36e 025aa78f7525da5fb9cbf06172207\#.U6ABkfks2uJ, 20140615.

${ }^{22}$ Rotar I., “Are There Possible Future ‘Crimeas' in Central Asia?”, Eurasia Daily Monitor, 201406 13, http://www.jamestown.org/single/?tx_ttnews\%5Btt_news\%5D=42504\&tx_ttnews\%5BbackPid\%5D=13\&c Hash=486c7fd807a9c10082658971bc4e99fd\#.U6ABePks2uI, 20140614.
} 
gas. Kirgizija, pagal ịvairių tarptautinių demokratijos tyrimų agentūrų vertinimus, yra laikoma pusiau atviru režimu. O Turkménistanas yra itin uždaras ir valdomas sultono. Galima teigti, kad Centrinès Azijos valstybès skiriasi ekonomikos išsivystymo lygiu, atsparumu išorès poveikiui. Kazachstano, o ypač Uzbekistano ekonomikos yra sąlyginai stiprios, Uzbekistano ekonomika net išlaikè augimo tendenciją paskutiniosios pasaulio finansų krizès metu. $\mathrm{O}$ Tadžkistanas yra viena neturtingiausių pasaulio valstybių. Šios šalies, o taip pat Kirgizijos ekonomika yra silpniausios regione. Dujų išteklių turtingas Turkmėnistanas kol kas stipriai priklausomas nuo Rusijos, kuri iki 2009 metu buvo vienintelis jo eksporto partneris. Situacija stipriai keičiasi Kinijai plètojant dujotiekio infrastruktūrą regione. Vis tik, šie Centrinès Azijos valstybių tarpusavio skirtumai atspindi tos pačios geopolitinès, geoekonominès ir geokultūrinès kokybės kiekybinius niuansus, kurie neužgožia panašumų, išskiriančių Centrinę Aziją kaip regioną iš gretimos supančios aplinkos.

Centrinès Azijos regionas pasižymi silpna politine ir ekonomine čia esančių valstybių integracija ir žemu bendradarbiavimo lygiu. Vis tiek sisteminio pobūdžio sąveikos, apibūdinančios Centrinès Azijos regioną kaip sistemą yra gana akivaizdžios. Pagrindinès jų vyksta geoekonominëje ir geopolitinèje plotmëje. Vienas svarbiausių jas sąlygojančių veiksnių - netolygus gamtinių resursų, ypač vandens, pasiskirstymas regione. Jų perskirstymo būtinybė generuoja vieną iš sisteminių sąveikų tarp regiono valstybių. Kitą šiai sistemai būdingą sąveiką sukelia bendros energetinès ir transporto infrastruktūros būtinybė. Tokia būtinybė yra geografiškai determinuota, be to, nuo infrastruktūrinių klausimų sprendimų tiesiogiai priklauso kiekvienos regiono valstybès ekonomikos vystymosi perspektyvos, ypač turint galvoje, kad nẻ viena regiono valstybè neturi prièjimo prie jūros. Geopolitinio ir geokultūrinio pobūdžio sisteminès sąveikos daugiausia sietinos su postkomunistine regiono būkle ir jo lokalizacija civilizacijų paribyje. Šios sąveikos, regis, lemia tai, jog Centrineje Azijoje kristalizuojasi geopolitinis kodas - šalys gana panašiai apibréžia savo nacionalinius interesus, identifikuoja grèsmes, formuluoja ir igyvendina užsienio politiką.

Eskaluojant Ukrainos įvykius, o ypač Rusijai aneksavus Krymą, Vakarų politinis aktyvumas Centrinèje Azijoje pastebimai padidejjo. NATO atidarè atstovybę Taškente ${ }^{23}$, atrodo, vienintelę Centrinèje Azijoje. 2014 m. gegužès 5-6 dienomis Kazachstaną ir Uzbekistaną aplankẻ JAV valstybės sekretoriaus pavaduotojas Williamas J. Burnsas. Tarp svarbiausių susitikimų temų pirmiau-

\footnotetext{
${ }_{23}$ "NATO Opens New Office in Uzbek Capital", World Bulletin, 201405 17, http://www.worldbulletin.net/ world/136595/nato-opens-new-office-in-uzbek-capital, 20140611.
} 
sia minima situacija Ukrainoje, Afganistano reikalai ir Kazachstano narystès Pasaulio prekybos organizacijoje perspektyvos ${ }^{24}$. Pastebima, kad visos šios aptarti pasiūlytos temos yra Vakarų geopolitinès traukos lauke, tad iš esmès Burnso vizitu greičiausiai buvo siekiama dar kartą aktualizuoti pagrindinius Kazachstano ir Uzbekistano bendradarbiavimo su JAV ir NATO aspektus.

Rusija taip pat stengiasi užsitikrinti bent jau dalies savo Centrinès Azijos kaimynų paramą. Vèlyvą 2014-ųjų lapkritị Rusijos Federacijos Prezidentas V. Putinas lankėsi regione. Tuomet Rusija nurašè beveik visą 890 mln. JAV dolerių Uzbekistano skolą ir suteike naujas paskolas rusiškai ginkluotei ir karinèms technologijoms įsigyti ${ }^{25}$. Tačiau, Rusijos ekonominè situacija Centrinei Azijai artimiausioje ateityje gali sukelti nemažai rimtų problemų. Artimiausioje ateityje Centriné Azija veikiausiai patirs Vakarų ekonominių sankcijų Rusijai poveikị. Rusijoje dirba daugybė migrantų iš Centrinès Azijos, ypač iš Tadžikistano, Kirgizstano ir Uzbekistano. Jų piniginès perlaidos sudaro svarią šiu valstybių ekonomikos dalị. Vakarų sankcijoms vis labiau slegiant Rusijos ekonomiką, tikètinas gausus migrantų srautas atgal ị Centrinę Aziją, o tai destabilizuotų regioną.

Dar vèliau Rusijai gresia būti išstumtai iš Centrinès Azijos dujų ir naftos rinkos. Vakarų nuostatos mažinti energetinę ES priklausomybę nuo Rusijos, ar net visiškai atsisakyti tiekimo iš šios šalies, per ilgą laiką gali labai keisti energetinių išteklių Europoje paklausos ir pasiūlos struktūrą. Jei Rusijai būtų apribota arba visai užverta prieiga prie Vakarų rinkų, energetinius išteklių srautą ji veikiausiai nukreiptų i Kiniją. Tačiau Centrinejje Azijoje Kinija pati plètoja tiesioginių dujotiekių ir naftotiekių projektus, tad šiame regione Rusijos energetinio tarpininkavo jai nereikia. Jei aplinkybės klostytųsi tokia linkme, ir jei nepavyktų gana greitai igyvendinti infrastruktūrinių projektų, siejančių Centrinę Aziją su Afganistanu ir Pakistanu, energetinių išteklių gavyba ir transportavimas Centrinëje Azijoje Rusijai gali tapti ekonomiškai nebetikslingas.

Vakarams ir Rusijai traktuojant vienas kitą kaip galimą priešininką, JAV gali netekti prieigų prie Centrinès Azijos sausumos ir oro transporto infrastruktūrų. Tai gerokai pasunkintų vykimą i Afganistaną ir verstų ieškoti alternatyvų. Vakarams greičiausiai tektų grịžti prie 2008-aisiais metais svarstytų tranzito variantų, kuriuose buvo numatyta aplenkti Rusijos teritoriją, keliant krovinius per Kaspijos jūrą. Akivaizdu, kad Rusija pati prarastų dalị pajamų,

\footnotetext{
${ }^{24}$ „Deputy Secretary Burns Travel to Uzbekistan and Kazakhstan“, U.S. Department of State, Media Note, 201405 05, http://www.state.gov/r/pa/prs/ps/2014/05/225638.htm, 20140620.

${ }^{25}$ Sorbello P., “Yes, Uzbekistan is Putin's Friend“, The Diplomat, December 15, 2014, http://thediplomat. com/2014/12/yes-uzbekistan-is-putins-friend/, 20141215.
} 
dabar gaunamų už tranzitą per savo teritoriją. ${ }^{26}$ Tačiau, šiandien, kitaip negu 2008-aisiais metais, Vakarams Centrineje Azijoje gali tekti susidurti su dèl poliarizacijos besikeičiančia regiono valstybių politika jei Rusija nebeleistu gabenti NATO krovinių per savo teritoriją, neaišku, ar Vakarams pavyktų susitarti su Kazachstanu ir Turkménistanu - dviem regiono valstybėmis, turinčioms priejimą prie Kaspijos jūros.

Kita vertus, Rusija, net besireiškiant poliarizacijai, neturi geostrateginių argumentų, dèl kurių jai vertètų trukdyti JAV ir NATO tranzitui iš Afganistano. Netgi priešingai - tranzitas reikštų Vakarų karinio dalyvavimo regione mažejjimą ir galimybę Rusijai čia igyti karinès galios persvarą. Tiesa, dalis karinès technikos ir greičiausiai ginkluotès, pagal tarpvyriausybinius susitarimus, pasiliks tranzito valstybėse kaip užmokestis už leidimą naudotis teritorija ir infrastruktūra. Didžiausią Rusijos susirūpinimą turètų kelti dèl Vakarų tranzito liekanti karinè technika Uzbekistane. Tačiau politika, dèl kurios Vakarams tranzitas taptų sunkiai igyvendinamas, gali turèti dar didesnių nepageidaujamų pasekmių Rusijai. Išaugus transportavimo išlaidoms iki nepriimtino lygio, JAV ir NATO gali būti pigiau savo nuožiūra perduoti likusị Afganistane turtą kai kurioms kaimyninėms valstybėms, pavyzdžiui, Uzbekistanui, Pakistanui ar Tadžikistanui, arba tolimesnèms šalims, pavyzdžiui, Ukrainai (jos turètų išsigabenti karinius krovinius iš Afganistano savo sąskaita ir priemonèmis).

Jei iki Krymo aneksijos Centrinèje Azijoje besiklosčiusius didžiųjų veikejjų santykius galima apibūdinti kaip konkurenciją, tai vykstant poliarizacijai, regione gali atsirasti tiesioginių priešpriešų. Čia daug kas priklausys nuo Centrinès Azijos valstybių politikos, kuria iki šiol buvo siekiama balansuoti didžiųjų valstybių įtakas. Atrodytų, toks regiono valstybių užsienio politikos pobūdis sudarytų prielaidas čia susiformuoti buferinei zonai, neutralizuojančiai priešpriešines ịtakas. Tačiau Centrinès Azijos autokratijų pajègumas balansuoti jègas yra gana ribotas. Pirmiausia, visose regiono valstybėse palyginti lengva sukurstyti vidaus neramumus ir jas destabilizuoti. Centrinès Azijos režimai nuolatiniu persekiojimu, viena vertus, labai stipriai radikalizavo opoziciją, o kita vertus, sukūrè savo visuomenèse didelị atotrūkị tarp elito ir likusių gyventojų. Be to, sovietmečiu Centrinès Azijos valstybių sienos buvo demarkuotos taip, kad kiekvienoje valstybeje titulinè tauta sudarytų ne daugiau kaip $75 \%$ gyventojų. Nors po stalinistinių socialinių ir politinių eksperimentų praejo bemaž šimtmetis ir etninès proporcijos labai pasikeitè, Centrinès Azijos valstybès nuolat susiduria su jau minètų etninių konfliktų eskalacijos pavojumi. Be

\footnotetext{
26 "Uzbekistan: Tashkent Has the Power to Influence outcome of the Afghan War", Eurasianet, 200811 19, http://www.eurasianet.org/departments/insightb/articles/eav111908.shtml, 20140502.
} 
etninès įtampos, regionui būdingi vaidai tarp tai pačiai tautai priklausančių klanų ir valstybių sienas peržengiančių ekonominių-patronažinių tinklų. Tai dar vienas grèsmių šaltinis. Labiausiai tokioms grèsmėms neatsparios valstybès yra Tadžikistanas ir Kirgizstanas, o Uzbekistanas ir Kazachstanas santykinai stabilesnès. Regiono jautrumą ịvairioms destabilizuojančioms įtakoms papildomai didina silpnas bendradarbiavimas tarp Centrinès Azijos valstybių.

Savitas Centrinès Azijos autokratinių neopatrimonialistinių valstybių užsienio politikos bruožas yra tai, kad valstybès išorinio saugumo problematika suvokiama beveik išskirtinai per vidaus režimo išsaugojimo prizmę. Todèl, labiausiai tikètina bet kurios Centrinès Azijos valstybès tarptautinė elgsena vidinès grèsmès akivaizdoje - sąjunga su didžiąja valstybe, pasiūliusia tiesiogines saugumo garantijas valstybès vadovybei, pavyzdžiui, ịvedant kariuomenę ar teikiant kitokią karinę pagalbą. Panaši politika, kuri reiškẻsi strateginių partnerių kaitaliojimu kas keleri metai, buvo vykdoma Uzbekistane nuo pat jo nepriklausomybės pradžios. Kirgizstano ir Tadžikistano politiką Rusija dažnai ir gana lengvai radikaliai keisdavo pažadejjusi finansinę pagalbą. Pavyzdžiui, 2009 m. Rusijai pažadejjus, kad kompanija „INTER RAO“ investuos 2 mlrd. JAV dolerių i Kambara-Ata $1^{27}$ hidroelektrinès statybą, Kirgizstano vadovybe pareikalavo, kad JAV išvestų iš Manaso karinès bazės savo karius. Finansuodama arba staiga nutraukdama Roguno dambos projekto finansavimą ${ }^{28}$, Rusija iki šiol gana didelę įtaką daré Tadžikistano politikai.

Vienos kurios nors Centrinès Azijos valstybès strateginè partnerystė su Rusija ar Vakarais beveik neišvengiamai vestų prie viso regiono poliarizacijos. Šiame kontekste svarbūs Uzbekistano ir Kazachstano santykiai, kurie pasižymi nuolatine konkurencija dèl regiono lyderio vaidmens. Uzbekistanas paprastai iki šiol stengdavosi stabdyti Kazachstano integracines iniciatyvas, kuriose ižvelgdavo Rusijos politikos tąsą ir pavojų pakliūti ị Maskvos ịtakos zoną. Išimtị sudaro trumpas 2006-2007 metų laikotarpis, kai Uzbekistanas pasirašęs strateginès partnerystès sutartị su Rusija, turèjo su ja derinti savo regioninę politiką. Centrinèje Azijoje gilejjant priešpriešai tarp Rusijos ir Vakarų ir augant ittampai, Kazachstanas ir Uzbekistanas veikiausiai pasirinktų sąjungas su skirtingomis valstybėmis. Kazachstanas, savo valstybingumą grindžiantis eurazietiškumo idèja, tikètina stotų i Rusijos pusę ir, turèdamas stiprų Kinijos palaikymą, bandytų juo atsverti išaugusią Rusijos įtaką. Tokia Kazachstano pozicija

\footnotetext{
27 "Drilling Work Begins at 1900 MW Kambarata 1Hydropower Plant", Hydroworld.Com. 201308 22, http://www.hydroworld.com/articles/2013/08/drilling-work-begins-at-1-900-mw-kambarata-1-hydropower-plant.html, 20140615.

${ }^{28}$ Nuttall, Clare, “Tajikistan Going Rogun”, Business New Europe, 201309 19, http://www.bne.eu/content/ tajikistan-going-rogun, 20131025.
} 
veikiausiai verstų Uzbekistaną kurti partnerystę su JAV. Čia pasireikštų dar keli veiksniai. Pirmiausia, Uzbekistanas turi gana ilgo karinio bendradarbiavimo su JAV patirti, be to, tas bendradarbiavimas dabartiniu laiku intensyviai vyksta dèl NATO tranzito. Antra, Uzbekistanas visada labai ịtariai žiūrèjo ị Rusijos pastangas stiprinti karinị potencialą Centrinèje Azijoje ${ }^{29}$. Kirgizstanas su Tadžikistanu veikiausiai sektų paskui Kazachstaną, o Turkmėnistanas, tikètina, laikytųsi neutralumo. Tad, vykstant poliarizacijai, Centrinejje Azijoje gali susiformuoti regioninio balanso sistema, kurioje Kazachstanas ir Uzbekistanas varžytųsi dẻl lyderystės. Tarptautinių santykių istorija rodo, kad tokios sistemoms yra santykinai stabilios ${ }^{30}$, tad tikètina, kad per ją galètų būti palaikomas regiono stabilumas be tiesioginio Rusijos ar Vakarų ịsikišimo. Tokioje situacijoje labai svarbus vaidmuo tektų Kinijai ir jos dominuojamai Šanchajaus bendradarbiavimo organizacijai, jei tik iš organizacijos būtų visiškai pašalintas karinis dėmuo. Kinija būtų suinteresuota plètoti ekonominius santykius tiek su Kazachstanu, tiek ir su Uzbekistanu, tapdama papildomu stabilumo regione veiksniu.

Tačiau aptariama sistema veikiausiai patirtų ir destabilizuojančias įtakas. Per pastaruosius kelerius metus Centrinèje Azijoje suintensyvejjo islamo kovotojų veikla. Manoma, kad to priežastimi tapo nuolatinès ir sékmingos Pakistano kariuomenès operacijos prieš Šiaurès Vaziristane ịsikūrusias Talibano kovotojų bazes. Vietovei tapus nebesaugiai, islamo kovotojai ėmè traukti ị Centrinę Aziją. Dar didesnis pavojus per Uzbekistaną, Tadžikistaną bei Kazachstaną gabenami NATO kariniai kroviniai, galintys vienokiu ar kitokiu būdu atsidurti kovotojų rankose. 2009 metų vasario pradžioje prasidejjus NATO krovinių tranzitui per Uzbekistaną, Taškento turguose tuoj pat atsirado daugybė prekeivių, pardavinèjančių karines amerikiečių uniformas, avalynę ir ekipuotę $^{31}$. Turint galvoje Centrinés Azijos korupcijos mastus ${ }^{32}$, tikètina, kad islamo kovotojams gali būti tiekiami ginklai. Poliarizacijos tendencija aktualizuoja ši rizikos veiksnị. Stiprejjant priešpriešai ir regiono valstybems besirenkant partnerystę su skirtingų polių valstybėmis, tampa tikètinas ir terorizmo rèmimas, bandant nukreipti ji prieš priešininkus.

Kinija gali ne tik stabilizuoti tikètiną regiono sistemą, bet taip pat tapti patraukliu trečiuoju geopolitiniu vektoriumi Centrinės Azijos valstybėms.

\footnotetext{
${ }^{29}$ Najibullah F., „Eurasian Grouping Plans Regional Army Near Afghanistan“, Eurasianet, 200809 19, http://www.rferl.org/Content/CSTO_Regional_Army_Afghanistan/1201509.html, 20080921.

${ }^{30}$ Carpenter T. G., Innocent M., "The Iraq War and Iranian Power", Survival, vol. 49, No. 4, Winter 20072008, p.66-82.

${ }^{31}$ Asmenine autoriaus patirtis.

${ }^{32}$ Cooley A., "Great Games, Local Rules: The New Great Power Contest in Central Asia", New York: Oxford University Press, 2012, p. 99, 100, 166.
} 
Politinès ir ekonominès prielaidos Kinijai imtis savarankiško integruojamo vaidmens tiek Centrinëje Azijoje, tiek ir kituose Azijos regionuose, susiformavo per pastaruosius 10-15 metų. Kinijos investicijos savo dydžiu jau pranoksta Rusijos investicijas Centrinejje Azijoje ${ }^{33}$. Kinija sugebejjo išstumti Rusiją iš pagrindinio prekybos partnerio pozicijų Turkmėnistane - didžiausias gamtinių dujų atsargas turinčioje Centrinès Azijos valstybeje. Kinijos ekonominis-integracinis projektas „Šilko kelio ekonominè juosta“ (angl. Silk Road Economic Belt) nenumato nei Vakarų bendradarbiavimo pasiūlymuose būtinų demokratinių reformų ar žmogaus teisių sąlygų, nei reikalauja geopolitinių apsisprendimų, suponuojamų Rusijos integracinèse iniciatyvose. Tikètina, kad ateityje Kinijos ịsitraukimas ị regiono ekonomiką tik gilès.

Nors Rusijos taikyti Krymo aneksijos metodai Kinijai kelia rūpestį, stebima Rusijos ir Vakarų santykių poliarizacija Kinijai, atrodo, yra palankus veiksnys. Kur kas daugiau problemų Kinijai keltų, jei Rusija ir Vakarai taptų partneriais. Dèl gerų JAV santykių su Japonija, Taivanu ir Pietų Korëja, JAV ir Rusijos partnerystè faktiškai izoliuotų Kiniją tiek sausumoje, tiek ir jūroje. Kinija gali bandyti tarptautinių santykių poliarizacijos tendenciją išnaudoti savo lyderystei Azijoje įtvirtinti. Regis, galima stebèti tokios Kinijos politinès valios apraiškas. Kiek daugiau negu mènesiui praejus po Krymo aneksijos (2014 05 21), Šanchajuje buvo sušauktas 4-asis Sąveiką ir pasitikèjimą didinančių priemonių Azijoje konferencijos (CICMA) viršūnių susitikimas. Atsižvelgiant ị didelị organizacijos mastą ${ }^{34}$, galima teigti, kad susitikimo dokumentai atspindi bendrąsias Azijos valstybių saugumo ir stabilumo nuostatas. Renginio metu Kinija pasiūlè naują Azijos saugumo koncepciją, kuri galbūt rodo atsirasiant naują geopolitinę erdvę, atsparią Rusijos ir Vakarų poliarizacijai. Kinijos koncepcijoje pirmiausia akcentuojamos ne pačios grèsmès, o veikiau jų ịveikimo būdas Azijos saugumo užtikrinimas yra pačių Azijos šalių reikalas ${ }^{35}$. Ko gero, tokiu būdu Kinija iš esmès pareiškè, kad jei kas nors (konkrečiai - Rusija) tarptautiniuose santykiuose vadovausis geopolitine logika, tokiu atveju Kinija laikys kaimynines Azijos šalis savo įtakos zona. O Kazachstano Prezidento Nursultano Nazarbajevo pasiūlymas kurti Azijos saugumo ir plètojimo organizaciją (alternatyvą ESBO), regis palaiko Kinijos, o ne Rusijos dominavimo Centrinejje Azijoje idèją.

\footnotetext{
${ }^{33}$ Horák S., „Russia's Intervention in Ukraine Reverberates in Central Asia“, The Central Asia-Caucasus Analyst, 201403 19, http://www.cacianalyst.org/publications/analytical-articles/item/12935-russias-intervention-in-ukraine-reverberates-in-central-asia.html, 20140325.

${ }^{34}$ CICMA narès yra 26 Azijos valstybès, tarp jų Kinija, Indija, Rusija, Iranas, Irakas, Izraelis, Egiptas.

35 "Asian Security Should Rely on Asians: Xi”, CCTV.Com, 201405 21, http://english.cntv.cn/2014/05/21/ ARTI1400650658177308.shtml, 20140526.
} 


\section{Išvados}

Tarptautinių santykių poliarizacija sukelia polių nacionalinès ar pilietinès tapatybės pokyčius, susijusius su „mes“ ir „jie“ skirtimi. Galima būtų teigti, kad prasidejusi poliarizacija iggauna didesnį mastą ir tampa tarptautinių santykių pagrindu. Centrinès Azijos šalys vertina ir pasirenka vieną ar kitą polių, atrodo, apsvarsčiusios kiekvieno iš jų veikimo būdus ir pasirinkimo padarinius ateityje. Ši vertinimo ir pasirinkimo užduotis Centrinès Azijos valstybėms yra labai sunki, nes yra priešinga jų vykdomai daugiavektoriškai užsienio politikai, kurios esmę sudaro tokių vertinimų ir pasirinkimų vengimas. Kultūriniu-informaciniu požiūriu poliarizacijos veiksnị Centrinejje Azijoje pavyksta neutralizuoti neužimant aiškios pozicijos. Tai padaroma suskaidžius vertinamą objektą $\mathfrak{i}$ teigiamai ir neigiamai vertintinus aspektus.

Poliarizacijos ịtaką karinés galios dinamikai Centrinès Azijos valstybès vargu ar pajègios suvaldyti. Stebėdamos įvykius Ukrainoje, Centrinès Azijos valstybės pastebi tam tikrų požymių, kad galètų iškilti pavojus ir jų saugumui, jei tik Rusija priimtų atitinkamus politinius sprendimus. Tad Rusija Centrineje Azijoje vis labiau imama suvokti kaip potenciali karine grèsmè. Atrodo, tai turètų pastūmèti Centrinès Azijos valstybes atsigręžti ị Vakarus, tačiau Vakarai (kaip parode ịvykai Ukrainoje) yra inertiškas polius, besirenkantis nekarinị veikimo būdą. Todèl kurios nors Centrinès Azijos valstybès atsigręžimas ì Vakarus tai valstybei būtų pavojingas, nes grèstų karinis konfliktas. Ji taptų Rusijos karinès galios taikiniu, o tikimybė sulaukti adekvataus Vakarų karinio palaikymo yra labai nedidelè. Galbūt kiek didesnès Vakarų paramos galètų sulaukti Uzbekistanas dèl savo ligšiolinių, nors ir nenuoseklių, santykių su JAV.

Atsigręžusių i Vakarus Centrinès Azijos šalių ekonomikas pirmiausia paveiktų iš Rusijos grịžtantys emigrantai. Jei per gana trumpą laiką nebus išspręsta grịžtančių žmonių ịdarbinimo problema ar darbo jègai iš Centrinès Azijos neatsivertų alternatyvių Rusijai migracijos kelių, regione gali kilti rimtų socialinių problemų. Be to, Vakarams siekiant, kad ES taptų nepriklausoma nuo Rusijos energetinių išteklių, Rusijos veikla, susijusi su jų gavyba ir transportavimu Centrineje Azijoje, per ilgą laiką gali tapti jai ekonomiškai nenaudinga.

Stiprejant poliarizacijai už sistemos ribų, Centrinès Azijos atsparumas jos poveikiui silpnès. Tad, vienas iš galimų rezultatinių galios dinamikos regione variantų - politiškai stabilios regiono sistemos susiformavimas. Tokia sistema galètų formuotis aplink Kazachstano ir Uzbekistano aši; joje Kazachstanas, Tadžikistanas ir Kirgizstanas liktų Rusijos ịtakoje, o Uzbekistanas - Vakarų. 
Šioje situacijoje nèra galimybès Turkmėnistanui atsisakyti neutralumo, tad tikètina, kad jo politika kis mažai. Dèl Centrinès Azijos geostrateginès svarbos ir iš čia kylančiu šiuolaikinių grèsmių globalumo, tokia sistema galètų būti priimtina tiek Rusijai, tiek ir Vakarams.

Vykstant išorinei poliarizacijai , kitokią rezultatinę regiono galios tendenciją gali lemti Kinija. Ekonominès prielaidos tokiam vyksmui yra daugiau negu pakankamos. Šiandien pastebima, kad Kinija imasi iniciatyvos kurti Centrinès Azijos ir kitų jos regionų saugumo ir stabilumo sistemą, atsparią Aziją iš išorès skaidančioms ịtakoms. Dabartinèje situacijoje Kinijos geopolitinès traukos lauko pasirinkimas Centrinès Azijos valstybèms greičiausiai būtų saugiausias pasirinkimas Vakarų ir Rusijos įtakai atremti tiek kariniu, tiek ir ekonominiu požiūriu. Be to, tikètina, kad Kinijos geopolitinejje erdvèje tam tikru lygiu galètų būti ir toliau plètojamas Šilko kelio vaizdiniais besiremiantis Centrinių Azijos šalių identitetas ir ji puoselëjanti regiono valstybių daugiakryptè užsienio politika.

2014 m. gruodis 